\title{
THE CHANGING STRUCTURE OF STRUCTURAL FUNDS IN THE EUROPEAN UNION
}

\section{Nagihan OKTAYER*}

\section{Abstract:}

Greater equality across Europe in income and decreasing the regional disparities have been one of the central goals of the European Union since the early days of European integration. Various policy measures have been introduced in achieving this goal over the years. Structural funds are the most favorite instrument used by the European Union to reach this goal. The importance of the structural funds has increased over the course of the European Union's history. They went through many major reforms. The aim of this study is to analyse the main characteristics of the European Structural Policy. Institutional roots and the development of the Policy, principles of funding, objectives and tools, chancing structure of the Policy after 2007 and pre-accession aid to accession countries will be analyzed in this context.

Keywords: European Integration, Structural Funds, Cohesion Fund, Pre-Accession Aid.

\section{$\ddot{O}_{z e t:}$}

Avrupa Birliği'nde, ülkeler arasındaki gelir farklllıklarının azaltılması ve bölgeler arasindaki dengesizliklerin giderilmesi Birliğin ilk kuruluş ylllarindan itibaren temel hedeflerinden biri olmuştur. Söz konusu amaca ulaşmada Birlik tarafindan çeşitli araçlar gelişstirilmiştir. Bu araçlardan en önemlisi yaptsal fonlardir. Yıllar itibariyle gelişimi incelendiğinde yapısal fonların öneminin giderek arttı̆̆ görülmektedir. Söz konusu fonların etkinliğini artırmak ïzere çeşitli reformlar gerçekleştirilmiş ve bu reformlar neticesinde bir yandan fonlara ilişkin yapısal değişiklikler yaptlırken, diğer yandan da bu amaçla ayrilan kaynak miktarl giderek artmıştır. Bu çalışmanin amacl, Avrupa Birliği'ndeki yapısal fonların temel niteliklerini ve temel enstrümanların incelemek, tarihi perspektiften hareketle bu alanda gerçekleştirilen reformaları ele almak ve 2007 öncesi ve sonrasinda Fonların yapısindaki değişikliği ortaya koymaktır.

\footnotetext{
*Assist. Prof. Dr., İstanbul University, Faculty of Economics
} 
Anahtar Kelimeler: Avrupa Entegrasyonu, Yapısal Fonlar, Uyum Fonu, Katllim Öncesi Yardim.

\section{Introduction}

The European Union is an integration which has some deep political, economic and social goals. One of the most important goals of the Union is to promote regional development of its member states and to speed up the process of convergence. Structural policy is the most favourite policy tool used by the European Union to achieve this goal.

The main aim of the structural policy is to decrease the regional disparities within the European Union: the reduction of economic and social disparities between richer and poorer regions. The Structural and the Cohesion Funds are the European Union's main instruments for supporting social and economic restructuring across the European Union. They are used to tackle with regional disparities and support regional development.

Structural policy aims at helping relatively underdeveloped regions and regions which suffer from severe unemployment problems for some different reasons. In order to increase their economic and social standards as close as possible to the European Union averages, a considerable amount of money is spent every year from the Union budget. Among European Union policies, structural policy has probably the strongest redistributive effect: up to one-third of the Union budget goes to the less prosperous regions. Since 1975, when the main instrument of this policy - the European Regional Development Fund - was created, this policy has undergone some refoms (Brunazzo, Piattoni, 2004: 159).

The purpose of this paper is to examine the main characteristics of the European Structural Policy. Institutional roots and the development of the Policy, principles of funding, objectives and tools, chancing structure of the Policy after 2007 and pre-accession aid to accession countries will be analyzed in this context.

\section{Historical Background}

The roots of the European Union structural policy come from the Treaty of Rome. The preamble of the Treaty includes the commitment of the member states to

"ensure their harmonious development by reducing the differences existing among the various regions and the backwardness of the lessfavoured regions". 
Another important legal basis of the structural policy takes place in Article 158 of the Treaty:

"In order to promote its overall harmonious development, the Community shall develop and pursue its actions leading to the strengthening of its economic and social cohesion. In particular, the Community shall aim at reducing disparities between the levels of development of the various regions and the backwardness of the least favoured regions or islands, including rural areas. "

The tasks are thus specified in the founding Treaty as "reducing disparities", "reducing backwardness" and "redressing the main regional imbalances". Such deep targets imply not simply avoiding greater divergence among European regions, but effectively counteracting the possible centripetal effects of European integration and of all other factors contributing to the concentration of economic activity in core areas (Rodriguez-Pose\&Fratesi, 2004: 98).

Until the middle of 1970 s, regional policy in the Union was a domestic matter. However, several factors such as the proposed enlargement to include the United Kingdom and Ireland and contemporary initiatives for a deepening of European integration led to a greater focus on regional policy in the Union. Creation of the European Regional Development Fund was very important step towards the regional policy. By establishing it, the European Union aimed to redistribute part of the Member States's budget contributions to the poorest regions. Although modest at first, EU regional support through the structural funds has grown in importance over the years (Cappelen, et.al, 2003: 626).

Almost ten years later, the Single European Act created an incentive for a more substantive regional policy by bringing the concept of "economic and social cohesion". The Single European Act was a reform in this context. This reform was implying the coordination of the three Structural Funds (ERDF, ESF and EAGGF-Guidance Section) under the principles of territorial and financial concentration, programming, partnership and additionality. But, this reform implied not just the coordination of all existing funds under the umbrella of Structural Funds and comprehensive restructuring of the principles that guided their action, but also the doubling in relative terms of the monies committed to regional development from $15.1 \%$ of the European budget in 1988 to $30.2 \%$ in 1992 (RodriguezPose\&Fratesi, 2004: 98-99). 
In the following years, with the inclusion of economic and social cohesion as one of the Union's priorities alongside the Single Market and economic and monetary union, the Treaty of the European Union took the commitment one step further (De Rynck, McAleaey, 2001: 542). In 1992, the European Union decided to the creation of the Cohesion Fund to support the least prosperous Member States in their efforts towards economic convergence for preparation of economic and monetary union. Ireland, Greece, Spain and Portugal were the poorest Member States who had a gross national product of less than $90 \%$.

Eventually, from the historical perspective, the importance of the structural funds has increased over the course of the European Union's history. This is evidenced by the percentage of the Union's budget devoted to the funds. The structural funds, along with the cohesion fund, are one of the largest items of expenditures in the EU's budget. It should be noted that, the major impetus for this development came in February 1988 with the agreement of a five-year budget package that contained a commitment to double, in real terms, the resources available to the structural funds. The reform of the structural fund regulations in the same year was also central to the evolution of the policy sector. The regulations agreed in 1988 introduced a new framework through which the structural funds delivered financial aid aimed at reducing economic disparities among the Union's regions. (Sutcliffe, 2000: 290)

\section{Main Principles of Funding from the Structural Funds}

The structural policy is based on financial solidarity. This means that all regions and their citizens should be able to use all the advantages of a common market and the economic and monetary union and aid to underdeveloped regions in the process of restructuring so they will be able to respond to the strong competition in the single market.

Since 1988 reform, the Structural Funds are to be implemented in accordance with four main principles. It has to be noted that, beside these principles, the Structural Fund programmes should be consistent with local, regional, national and Community policies as well (Kuitunen, 2002: 49). The principles of funding are as follows:

i-Concentration,

ii-Partnership,

iii-Programming, iv-Additionality. 
The concentration principle refers to geographical concentration. It implies that funding should be strictly confined to the objects of the European structural policy. (Heijman, 2001: 168). In order to be as efficient as possible, funding programmes have to concentrate on some major objectives (Kuitunen, 2002: 51).

The main idea of Structural Funds reform performed in 1988 was to aid indigenous economic development by involving actors with knowledge of the particular local and regional problems. This principle is called as partnership. The partnership means that the carrying out of structural policy is done in close cooperation with national, regional and local authorities. The European Commission and all other relevant authorities discuss the allocation of the Funds. According to that principle, all stages in the implementation of the programmes should involve partnership between the relevant supranational, national, regional and local authorities (Heijman, 2001: 168; Kuitunen, 2002: 51).

The third principle of funding from structural policy is programming. This principle implies that the funding should be based on programmes rather than individual projects. Multiannual programmes are essential in the allocation of Funds.

Another principle of funding is additionality which means that member countries should cofinance programmes that are funded by European Structural Funds. The Funds are not intended to be used as a substitute for national funding but rather they provide additional assistance. The Member States are thus under the obligation to maintain their public expenditure at its level at the beginning of the programming period. On the other hand, the concept of additionality refers to the idea that the Funds should have additional impact on the regions (Heijman, 2001: 168; Kuitunen, 2002: 51).

\section{Instruments of Structural Policy}

The main financial instruments to implement the Structural Policy for the European Union are the Structural Funds and the Cohesion Fund.

\subsection{The Structural Funds}

The Structural Funds are basic and the oldest solidarity instruments. These instruments comprise four different types of funds:

i-European Social Fund (ESF),

ii-European Agricultural Guidance and Guarantee Fund (EAGGF),

iii-European Regional Development Fund (ERDF),

iv-The Financial Instrument for Fisheries Guidance (FIFG). 
The European Social Fund (ESF) is the oldest of the EU's four Structural funds. It was set up by the Treaty of Rome in 1958 to improve job opportunities in the Community by promoting employment and increasing the geographical and occupational mobility of workers. The Fund helps Member States combat unemployment, prevent people from dropping out of the labour market, and promote training to make Europe's workforce and companies better equipped to face new, global challenges (Boldrin, Canova, 2001: 223). The European Social Fund has naturally undergone many changes since its establishment with the evolution of the social and economic situation.

The "Guidance" section of the European Agricultural Guidance and Guarantee Fund (EAGGF) is the second component of the European Structural Funds. The main task of the Fund which was established in 1958 is to finance rural development measures and provide aid for farmers, mainly in regions lagging in development (European Commission, 2003).

The European Regional Development Fund was set up in 1975. By establishing it, the European Union aimed to redistribute part of the Member States' budget contributions to the poorest regions. The task of the Fund is to stimulate economic development in the least prosperous regions of the European Union. It focuses on infrastructures, productive investments, local development projects and provides aid for small firms. In terms of financial resources, the ERDF is by far the largest of the EU's Structural Funds (Boldrin, Canova, 2001: 223).

The Financial Instrument for Fisheries Guidance (FIFG) which was established in 1994 is a specific fund aimed only at the fishing industry. It replaced a number of smaller, separate instruments dating back to 1976 . It should generate growth in fishing employment, productivity, infrasructures and income. (Boldrin and Canova, 2001: 224) It helps adapt and modernize the fishing industry.

The bulk of the Structural Funds is allocated for three objectives (Edverveen, Gorter, 2002: 9):

-Objective 1 is to help lagging regions to catch up with the rest of Europe by providing basic infraștructure and encouraging business activity. Regions with a GDP per capita of less than $75 \%$ of the Union average qualify for this type of funding.

-Objective 2 is to help the economic and social restructuring of regions dependent on industries in decline, agriculture, fishery or areas suffering from problems related to urbanisation. In order to qualify for Objective 2 
funding, industrial regions must have an unemployment rate above the European Union average, a higher percentage of jobs in the industrial sector than the European Union average, and a decline in industrial mployment. In addition, regions must not be eligible for Objective 1 support.

-Objective 3 is to modernise education and increase employment. This jbjective refers to the whole of the Union. Any region can be eligible for bjective 3 funding, provided it does not receive Objective 1 funding.

Beside the three priority Objectives, the Structural Funds also provide inance through four Community Initiatives (CI) which are called as NTERREG III ${ }^{1}$, URBAN $\mathrm{II}^{2}$, LEADER $+^{3}$ and EQUAL ${ }^{4}$. These are rogrammes initiated by the Union to promote interregional cooperation in olving common problems. A small part of the Structural Funds goes to bese Initiatives. They are aimed at finding solutions to problems common 3 a number of or all Member States and regions: Interreg III for the evelopment of crossborder, interregional and transnational cooperation; IRBAN II to support innovative strategies in cities and urban eighbourhoods; LEADER + to promote rural development initiatives; QUAL to combat inequalities and discrimination in access to the labour jarket. The Community initiatives account for $5.35 \%$ of the Structural unds budget. (European Commission, 2004: 14)

Today, the Structural Funds cover about one third of the total European Inion budget and a large part of these Funds are allocated in the Objective regions.

Expenditure on Structural Funds was relatively small in the 970's, but it began to increase in the early 1980s to about EUR 7 illion by 1987. The Funds then underwent a significant trengthening that began to come through in the early 1990 s, reaching ome EUR 33.6 billion in 1999. In 1988, expenditure on the tructural Funds amounted to $19 \%$ of the Community budget. By 997 , this had increased to $25 \%$. A better indication of the chancing

Interreg III aims to stimulate cross-border, transnational and inter-regional Joperation.

Urban II encourages the economic and social regeneration of declining towns and ities with serious structural problems

Leadert promotes rural development.

Equal provides for the development of new ways of combating all forms of iscrimination and inequality in access to the labour market. 
volume of resources being devoted to the Structural Funds is to express it as a proportion of Community GDP.

Table 1: Expenditure on the Structural Funds (1987-2004)

\begin{tabular}{|c|c|c|}
\hline Years & $\begin{array}{c}\text { Total Amount } \\
\text { ECU, million } \\
\text { (current prices) }\end{array}$ & $\begin{array}{c}\text { Percentage of } \\
\text { European Union } \\
\text { GDP }\end{array}$ \\
\hline 1987 & 7000 & 0.18 \\
\hline 1988 & 8000 & 0.19 \\
\hline 1989 & 10000 & 0.22 \\
\hline 1990 & 12000 & 0.25 \\
\hline 1991 & 14000 & 0.27 \\
\hline 1992 & 16000 & 0.29 \\
\hline 1993 & 22000 & 0.40 \\
\hline 1994 & 23000 & 0.40 \\
\hline 1995 & 26000 & 0.40 \\
\hline 1996 & 28000 & 0.42 \\
\hline 1997 & 30000 & 0.42 \\
\hline 1998 & 31800 & 0.43 \\
\hline 1999 & 33600 & 0.43 \\
\hline 2000 & 32045 & 0.40 \\
\hline 2001 & 31455 & 0.38 \\
\hline 2002 & 30860 & 0.35 \\
\hline 2003 & 30285 & 0.34 \\
\hline 2004 & 29595 & 0.32 \\
\hline
\end{tabular}

Source: Eurostat, 1999.

Table 1 indicates that Structural Funds amounted to approximately $0.18 \%$ of EU GDP in 1987 , but this had risen to $0.43 \%$ by 1999 . Since then, expenditure has fallen back somewhat to EUR 29.6 billion or $0.32 \%$ of EU GDP by 2004. The general periods of policy intentensity are thus a relatively weak period from the mid-1970s to approximately 1988 , fallowed after 1988 by a period of increasing strength that continues through the 1990 s into the early 2000 s.

\subsection{The Cohesion Fund}

Another major component of the Stuructural Policy is the Cohesion Fund. It is a special Fund which was designed in 1993 under the Maasricht Treaty to assist the least prosperous Member States in their preparation for Economic and Monetary Union. Without the money from Cohesion Fund 
the southern countries were not willing to approve the monetary union and the northern enlargement in 1995 (Fenge, Wrede, 2004: 1). The Cohesion Fund differs from the Structural Funds in that it is based on Member States rather than regions. Member States are eligible for Cohesion funding, while eligibility for the Structural Funds is usually specific to certain regions (Boldrin, Canova, 2001: 224). The Member States whose per capita GDP, measured in purchasing power parity, is less than $90 \%$ of the EU average are eligible for funding. The projects only in the field of the environment and trans-European transport infrastructure networks are financed by Cohesion Fund. The original beneficiary countries were the Greece, Portugal, Ireland and Spain, but as from 1 May 2004, with the accession of new Member States, some new countries became eligible for Cohesion support.

The total Cohesion Fund budget for 2000-2006 amounted to EUR 18 billion for the EU-15. It increased from EUR 1.5 billion in 1993 to more than EUR 2.6 billion in 1999. In July 2004, the Commission published proposed new regulations for the Structural Funds for the programming period 2007-2013. Under these regulations, the Cohesion Fund was accepted as being one of three Funds that remain as instruments for the Convergence objective. Eligible investment projects include transEuropean transport net-works, sustainable transport, the environment and renewable energy (Florio, 2006: 213)

The Member States submit a list of proposals to the European Commission each year, and projects are selected and implemented by the country concerned, which is also responsible for management and financial monitoring. However, the Commission is responsible for the final co-financing decision and regularly monitors projects. The project priorities are decided jointly by the European Comission and the Member States. From 1995, the Commission has decided to ensure that $50 \%$ of the Cohesion Fund is targeted at environment projects linked to the implementation of the Union's environmental policy. The distribution of commitments to specific environment and transport sectors by country for 1993-1999 is detailed in Table 2 (Florio, 2006: 213). 
Table 2: Allocation of Cohesion Fund by Projects (EUR Million)

\begin{tabular}{|l|r|r|r|r|r|r|}
\hline $\begin{array}{l}\text { Projects } \\
\text { Funded by } \\
\text { Cohesion } \\
\text { Fund }\end{array}$ & Spain & Greece & Portugal & Ireland & Total & $\begin{array}{c}\text { Share of } \\
\text { Projects(\%) }\end{array}$ \\
\hline Environment & $\mathbf{4 6 5 4}$ & $\mathbf{1 4 6 4}$ & $\mathbf{1 5 5 9}$ & $\mathbf{7 4 7}$ & $\mathbf{8 4 2 4}$ & $\mathbf{5 0 . 3}$ \\
\hline $\begin{array}{l}\text { Drinking } \\
\text { water }\end{array}$ & 1211 & 615 & 508 & 251 & 2582 & 15.4 \\
\hline Sanitation & 2068 & 710 & 552 & 480 & 3810 & 22.75 \\
\hline Solid waste & 481 & 21 & 437 & 9 & 948 & 5.65 \\
\hline Other & 804 & 119 & 62 & 7 & 992 & 5.90 \\
\hline Transport & $\mathbf{4 5 9 7}$ & $\mathbf{1 5 3 5}$ & $\mathbf{1 4 4 6}$ & $\mathbf{7 4 8}$ & $\mathbf{8 3 2 6}$ & $\mathbf{4 9 . 7}$ \\
\hline Road & 2609 & 680 & 856 & 463 & 4608 & 27.5 \\
\hline Rail & 1860 & 484 & 334 & 119 & 2797 & 16.7 \\
\hline Airport & 73 & 260 & 160 & 3 & 496 & 2.96 \\
\hline Seaport & 25 & 78 & 96 & 39 & 238 & 1.40 \\
\hline Other & 29 & 32 & 0 & 6 & 67 & 0.40 \\
\hline Total & $\mathbf{9 2 5 1}$ & $\mathbf{2 9 9 8}$ & $\mathbf{3 0 0 5}$ & $\mathbf{1 4 9 5}$ & $\mathbf{1 6 7 5 0}$ & 100 \\
\hline $\begin{array}{l}\text { Share of } \\
\text { Countries (\%) }\end{array}$ & $\mathbf{5 5}$ & $\mathbf{1 8}$ & $\mathbf{1 8}$ & $\mathbf{9}$ & $\mathbf{1 0 0}$ & \\
\hline
\end{tabular}

Source: European Commission, 2003: Annual Report of the Cohesion Fund.

The large share of cohesion support goes to poorer regions and member states. As it was mentioned above, the funds allocated to Objective 1 are given to regions with a GDP per capita of less than $75 \%$ of the EU average, while the Cohesion Fund goes to member states with a GDP of $90 \%$ of the EU average. Since the poorest regions tend to lie in the poorest member states, one may expect that redistribution materialises at both the level of the regions and of the member states (Ederveen, et al., 2003: 7).

For the period 2000-2006, EUR 213 billion was earmarked for all structural instruments for the EU-15. In addition, about EUR 22 billion in pre-accession aid, and another EUR 22 billion in structural interventions for the new Member States in the period 2004-2006 was spent within the Union's adjusted financial perspectives. The total represents $37 \%$ of the EU budget for the 2000-2006 period (European Commission, 2004: 12). 


\section{Table 3: Structural Funds and Other Instruments for EU-15} (2000-2006)

\begin{tabular}{|l|r|r|r|r|r|r|r|r|r|}
\hline $\begin{array}{c}\text { Member } \\
\text { States }\end{array}$ & Obj. 1 & Obj. 2 & Obj. 3 & FIFG & $\begin{array}{c}\text { Cohesion } \\
\text { Fund }\end{array}$ & Cls & Total & $\begin{array}{r}\text { Popul. in } \\
\text { (O1+O2) } \\
\text { areas(\%) }\end{array}$ & $\begin{array}{c}\text { Allocation } \\
\text { by } \\
\text { Country }\end{array}$ \\
\hline Austria & 288 & 740 & 585 & 0 & 0 & 395 & 2008 & 28.2 & 0.9 \\
\hline Belgium & 690 & 486 & 817 & 33 & 0 & 231 & 2257 & 12.5 & 1.0 \\
\hline Denmark & 0 & 199 & 397 & 221 & 0 & 92 & 909 & 10.2 & 0.4 \\
\hline Finland & 1008 & 541 & 442 & 33 & 0 & 280 & 2304 & 51.7 & 1.0 \\
\hline France & 4201 & 6569 & 5013 & 254 & 0 & 1155 & 17192 & 34.0 & 7.4 \\
\hline Germany & 22035 & 3776 & 5057 & 121 & 0 & 1775 & 32765 & 29.8 & 14.0 \\
\hline Greece & 23143 & 0 & 0 & 0 & 3388 & 952 & 27483 & 100.0 & 11.8 \\
\hline ireland & 3409 & 0 & 0 & 0 & 584 & 183 & 4177 & 26.6 & 1.8 \\
\hline ttaly & 24424 & 2749 & 4129 & 110 & 0 & 1294 & 32707 & 46.5 & 14.0 \\
\hline Luxemburg & 0 & 44 & 44 & 0 & 0 & 14 & 103 & 28.2 & 0.0 \\
\hline Netherlands & 136 & 861 & 1866 & 33 & 0 & 719 & 3615 & 15.0 & 1.5 \\
\hline Portugal & 21010 & 0 & 0 & 0 & 3388 & 741 & 25139 & 66.0 & 10.8 \\
\hline Spain & 42061 & 2904 & 2363 & 221 & 12357 & 2162 & 62067 & 80.7 & 26.6 \\
\hline Sweeden & 797 & 431 & 795 & 66 & 0 & 307 & 2396 & 18.9 & 1.0 \\
\hline UK & 6902 & 5068 & 5046 & 132 & 0 & 1061 & 18209 & 32.2 & 7.8 \\
\hline EU-15 & 150104 & 24367 & 26553 & 1226 & 19717 & 11361 & 233328 & 40.3 & 100.0 \\
\hline
\end{tabular}

Source: (European Commission, 2004: 13)

Table 3 gives an overview of the distribution of resources across objectives and countries for the 2000-2006 period. As it is seen from the table, during this period Objective 1 support was by far the most important. Another point which should be noted that each member state received at least some support. In terms of Objective 1, the most funds were received by Spain, Italy and Greece in this period. The most funds in Objective 2 were allocated to France, the United Kingdom and Germany. These countries also got the most through Objective 3 . The countries that were given the largest share of total support were Spain, Italy, Germany, Greece and Portugal. Luxemburg and Denmark missed out on Objective 1 support because these countries have no lagging regions. Because all their regions qualify for Objective 1, Greece, Ireland and Portugal didn't get Objective 2 and 3 support in this period.

\section{Nature of the Structural Funds After 2007}

Some new regulations for the Structural Funds and the Cohesion Fund were adopted in the European Union for 2007-2013 financial period. These regulations provide the legal basis for the Structural Funds and the cohesion policy for this period. The Structural Fund Regulation for 2007-2013 has introduced significant changes to the rules governing European Union funding. There are three new "Objectives" instead of nine for targeting 
Structural Funds in 2007-2013 programming period. These objectives are achieved by three financial insturments; Cohesion Fund, European Regional Development Fund and European Social Fund.

Table 4: Structural Funds: Instruments and Objectives in the Past and Today

\begin{tabular}{|c|c|c|c|}
\hline \multicolumn{2}{|c|}{ 2000-2006 Financial Period } & \multicolumn{2}{|c|}{ 2007-2013 Financial Period } \\
\hline Objectives & $\begin{array}{l}\text { Financial } \\
\text { Instruments }\end{array}$ & Objectives & $\begin{array}{l}\text { Financial } \\
\text { Instruments }\end{array}$ \\
\hline Cohesion Fund & Cohesion Fund & & \\
\hline Objective 1 & $\begin{array}{l}\text { ERDF } \\
\text { ESF } \\
\text { EAGGF (Guidance) } \\
\text { FIFG }\end{array}$ & $\begin{array}{l}\text { Convergence and } \\
\text { Competitiveness }\end{array}$ & $\begin{array}{l}\text { Cohesion Fund } \\
\text { ERDF } \\
\text { ESF }\end{array}$ \\
\hline Objective 2 & $\begin{array}{l}\text { ERDF } \\
\text { ESF } \\
\end{array}$ & $\begin{array}{l}\text { Regional } \\
\text { Competitiveness }\end{array}$ & \\
\hline Objective 3 & ESF & $\begin{array}{l}\text { and Employment } \\
\text {-regional level } \\
\text {-national level: } \\
\text { European } \\
\text { Employment } \\
\text { Strategy }\end{array}$ & $\begin{array}{l}\text { ERDF } \\
\text { ESF }\end{array}$ \\
\hline Interreg & ERDF & \multirow{4}{*}{$\begin{array}{l}\text { European } \\
\text { Territorial } \\
\text { Cooperation }\end{array}$} & \multirow{4}{*}{ ERDF } \\
\hline Urban & ERDF & & \\
\hline Equal & ESF & & \\
\hline Leader + & EAGGF (Guidance) & & \\
\hline $\begin{array}{l}\text { Rural development } \\
\text { and restructuring of } \\
\text { the fisheries sector }\end{array}$ & $\begin{array}{l}\text { EAGGF (Guidance) } \\
\text { FIFG }\end{array}$ & & \\
\hline Nine Objectives & Six Instruments & Three Objectives & Three Instruments \\
\hline
\end{tabular}

Source: European Commission, 2004:29.

The convergence objective replaced the Objective 1 and the Cohesion Fund of the 2000-2006 period. It supports the economic convergence of the poorest Member States and regions of the Union. Regions with Gross Domestic Product per head is less than $75 \%$ of the EU average are eligible for Convergence funding from the European Social Fund and European Regional Development Fund. Furthermore, Members States whose Gross Domestic Product is less than $90 \%$ of the EU average are eligible for the 
Cohesion Fund, which continues to finance programmes in the areas of transportation and the environment.

The Regional Competitiveness and Employment Objective replaced the Objective 2 and 3. It supports projects to strengthen competitiveness, employment and skills in all areas that are not eligible for the Convergence Objective. This Objective aims at increasing regions' competitiveness and attractiveness, as well as employment through a two-fold approach. First, development programmes help regions to anticipate and promote economic change through innovation and the promotion of the knowledge society, the protection of the environment, and the improvement of their accessibility. Second, more and better jobs are supported by adapting the workforce and by investing in human resources (Inforegio, Factsheet, 2006). This Objective is performed through the European Social Fund and European Regional Development Fund.

European Territorial Cooperation Objective is the last objective of the current financial period. It replaced the Interreg Community Initiative and finances cross-border and transnational cooperation projects. The fund serving for this objective is the European Regional and Development Fund.

During the 2007-20I3 financial period, the key priority of the cohesion policy is the promotion of growth and jobs in all EU regions and cities. For this purpose, EUR 308 billion was earmarked from the budget. This is very significant and the greatest investment ever made by the Union through the Structural Funds and the Cohesion instrument. $81.5 \%$ of the total amount is allocated to the "Convergence" objective, under which the poorest Member States and regions take place. In the remaining regions, $16 \%$ of the Structural Funds is concentrated on supporting innovation, sustainable development, better accessibility and training projects under the "Regional Competitiveness and Employment" objective. The final $2.5 \%$ of the Funds support cross-border, transnational and interregional cooperation under the "European Territorial Cooperation" objective.

The allocation of the Structural Funds by member states and the objectives is shown in Table 5. The biggest share of the funds will go to the Poland (\%19.4) in 2007-2013 period. Spain, (\%10.2), Italy (8.3), Czech R. (7.7), Germany (\%7.6), Hungary (\%7.3), Portugal (\%6.2) and Romania $(\% 5.6)$ are the following most beneficiaries of the Structural Funds. 
Table 5: Allocation of the Structural Funds by Objective and Member States in 2007-2013 (Million Eur, 2004 Prices)

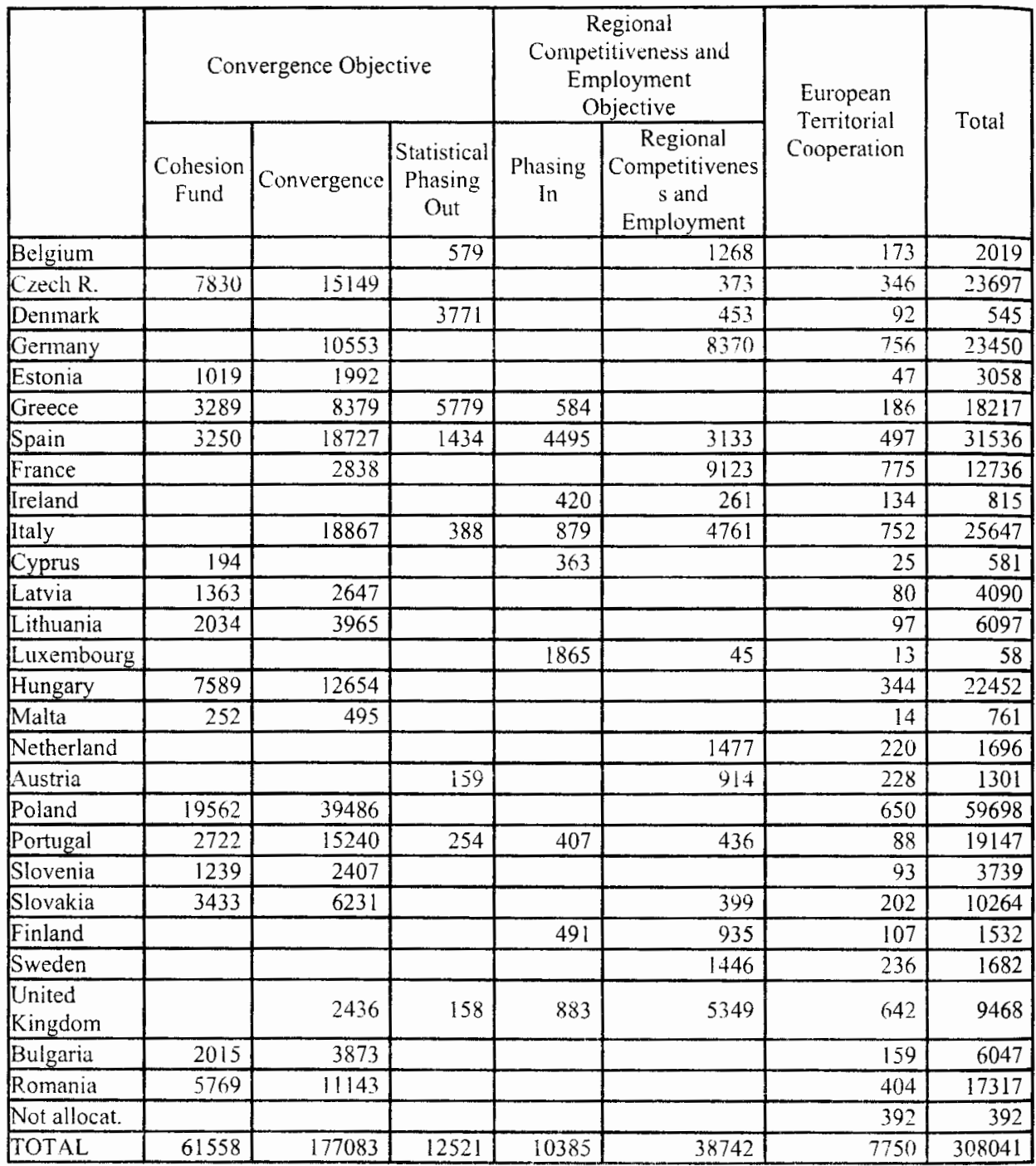

Source: Inforegio, 2006, Factsheet.

In order to provide further help to regions and cities to improve the quality of their investment, and, to lever further private investment to support the growth and jobs agenda, some new instruments were also developed for the period 2007-2013. In cooperation with the European Investment Bank and other financial institutions, the European Commission has launched three new initiatives for cohesion policy; Jaspers, Jeremie and 
Jessica. These initiatives are aimed to provide expert assistance to Member States and regions in the preperation of major projects (Inforegio, 2005: 2).

Jaspers (Joint Assistance in Supporting Projects in European Regions) is a kind of input to the preparation of applications for EU funding. It is expected to help the national and regional authorities to prepare large infrastructure projects. It offers a comprehensive technical assistance to the beneficiary Member States at no cost. This technical assistance is offered, as required, from the early stages of project through to the decision to grant assistance. Preparation of a project by Jaspers does not guarantee approval of the project by the Commission. Jaspers focuses its action on large projects supported by the EU funds'. (European Commission, COM (2006), http://ec.europa.eu/regional_policy/funds/2007/jjj/jaspers_en.html).

Jeremie (Joint European Resources for Micro to Medium Enterprises) is the second initiative of the Union together with the European Investment Bank and the European Investment Fund. It aims to provide increased access to finance for the development of micro, small and medium-sized enterprises in the regions of the European Union. Improving access to finance is a priority area of the renewed Lisbon agenda for growth and jobs in an effort to increase the availability of capital in Europe for new business formation and development. Past experience has shown that this is an area where the programme authorities would like to do more, but they lack both expertise and access to risk capital. Jeremie, by creating a framework for cooperation with the specialised financial institutions, is designed to help to overcome these difficulties (European Commission, COM (2006); http://ec.europa.eu/regional_policy/funds/2007/jjj/jeremie_en.html).

Jessica (Sustainable Development for Urban Areas) is the last initiative of the Commission in this context. It aims to provide solutions to the financing of projects for urban renewal and development using a combination of grants and loans. (European Commission, COM (2006); http://ec.europa.eu/regional policy/funds/2007/jjj/jessica en.html).

\section{Pre-Accession Aid in the Context of the Structural Policy}

The European Union developed a number of pre-accession aid programmes to assist candidate countries to carry out the reforms required and to prepare them to benefit from EU Structural Funds on accession. The most important and the richest programmes used in the 2000-2006 financial period are PHARE, ISPA, SAPARD, Pre-accession Instrument for Turkey

\footnotetext{
${ }^{\prime}$ Costing more than 25 million Euro for environment projects and more than 50 million Euro in transport and other fields.
} 
and the Community Assistance for Reconstruction, Development and Stabilization program for the Western Balkans.

PHARE $^{1}$ (Poland and Hungary: assistance for restructuring their economies) was developed in 1989. This programme was intended to act as a bridge for candidate countries in acquiring the acquis and preparing for Structural Funding. It was thus designed to play a crucial role in preparing for an enlargement that will pose particular problems for EU regional policy given both the low GDP per capita of candidate countries as well as their centiralized administrative structure. It consantrated on the building of necessary institutions to ensure the application of Community legislation (Bailey, Propris, 2004: 77). It also addressed for the funding of investment programmes in the candidate countries during the 2000-2006 period.

ISPA $^{2}$ (instrument for structural programmes for pre-accession) was created in 1999. This fund was used in financing important projects for the protection of the environment and in building transport infrastructure.

SAPARD $^{3}$ (special accession programme for agriculture and rural development) was another instrument of the Union developed as preaccession programme in 1999. This programme was designed to help candidate countries in solving problems of structural adjustments in the sector of agriculture and to provide assistance in implementation of the acquis in the area of Common Agricultural Policy.

Over the years, the EU's pre-accession financial aids were delivered through a variety of overlapping programmes suchlike. This aid system resulted in dispersed and complicated procedures. The aims of different programmes were not aligned with each other. Eventually, the requirement for the unification of the pre-accession aid programmes has arised.

In order to consolidate all these dispersed financial aid programmes, the European Commission created a new Instrument for Pre-accession Assistance (IPA) from January 2007. The new IPA superseeded the five preceding instruments - Phare, Ispa, Sapard, Turkey pre-accession instrument and Cards.

The IPA aims at supporting the EU candidate and potential candidate countries in their efforts to come closer to European standards and policies. It provides assistance in necessary reforms which are required for the EU

'Established by Council Regulation No. $3905 / 89$

${ }^{2}$ Established by Council Regulation No. 1267/99.

${ }^{3}$ Established by Council Regulation No. 1268/99. 
membership, including the adoption of EU values, laws and standards. IPA consists of five components to provide for targeted and effective assistance for each country according to its needs and evolution. These components are (Inforegio, October 2006):

- transition assistance and institution building,

- regional and cross-border cooperation,

- regional development,

- human resources development,

- rural development.

The first two components apply to both candidate and potential candidate countries, helping to strengthen democratic institutions and the rule of law, reform public administrations and promote economic reforms. The last three components apply just to candidate countries, preparing them with the adoption and implementation of the "acquis communautaire" and especially to prepare for the implementation of the EU's agricultural and cohesion policies. Because Turkey, Croatia and the Former Yugoslav Republic of Macedonia are the candidate countries, they are eligible for all components of the IPA. However, Serbia, Kosova, Montenegro, Bosnia and Herzigovina and Albania will receive assistance just through the first two components of this instrument (Inforegio, October 2006).

The IPA is based on strategic multi-annual planning established in accordance with the broad political guidelines set out in the Commission's Enlargement package, which now includes a multi-annual financial framework. The planning is made up of multi-annual indicative planning documents, established for each beneficiary country and covering the main intervention areas anticipated for that country. The Commission arrange its political priorities and financial allocations in a Multi-Annual Financial Framework on a three year basis. Then, for each beneficiary country, the Commission devises a Multi-Annual Indicative Planning Document, outlining its assistance priorities. This Document is prepared on a three year basis as well. Finally, an Annual Programme is adopted for each country by using this Multi-Annual Indicative Planning Document.

The overall IPA budget for the period from 2007 to 2013 is about EUR 11.5 billion. Because of its size, Turkey will get the biggest share of the funding. The allocation by country in the first three year period is set out below:

1 "Acquis Communautaire" refers to the total body of EU law accumulated thus far. 
Table 6: Pre-Accession Assistance (2007-2009, Eur Million)

\begin{tabular}{|l|r|r|r|r|}
\hline Country & \multicolumn{1}{|c|}{$\mathbf{2 0 0 7}$} & \multicolumn{1}{c|}{$\mathbf{2 0 0 8}$} & \multicolumn{1}{c|}{$\mathbf{2 0 0 9}$} & \multicolumn{1}{c|}{ Total } \\
\hline Turkey & 497.2 & 538.7 & 566.4 & 1602.3 \\
\hline Croatia & 138.5 & 146.0 & 151.2 & 435.7 \\
\hline F. Yugoslav R. of Macedonia & 58.5 & 70.2 & 81.8 & 210.5 \\
\hline Serbia & 186.7 & 190.9 & 194.8 & 572.4 \\
\hline Albania & 61.0 & 70.7 & 81.2 & 212.9 \\
\hline Bosna and Herzegovina & 62.1 & 74.8 & 89.1 & 226 \\
\hline Montenegro & 31.4 & 32.6 & 33.3 & 97.3 \\
\hline Kosova & 63.3 & 64.7 & 66.1 & 194.1 \\
\hline
\end{tabular}

Source: European Commission, 2006, Memo/06/410.

\section{Conclusion}

Along with the single market and monetary union, the EU's structural policy, especially cohesion policy functions as one of the three pillars in the construction of a European political and economic space. It is the only policy of the Union that explicitly addresses economic and social inequalities. It helps in transferring resources from the wealthier parts of the EU to the poorer ones. So, structural and cohesion funds are very specific instruments involving a redistribution mechanism via the budget of the EU for the purpose of supporting economic growth and sustainable development through investment in people and in physical capital.

The importance of the structural funds has increased over the course of the European Union's history. They went through many major reforms. Firstly, the financial resources allocated to these funds were significantly increased in the context of the reforms. Secondly, the structure of the funds has been changed after 2007 . The objective of these reforms was to make the funds more effective in reducing the gap between advanced and lessadvanced regions, and strengthening economic and social cohesion in the European Union.

Despite the significant achievements of structural policy to date, major disparities still remain across the Union. Deep-rooted structural problems exist in both rural and urban localities and regions of the current EU-27 and some of these will continue.

Latest information released by Eurostat shows that the three leading regions in the ranking of regional GDP per habitant in 2003 were Inner London ( $278 \%$ of the average), Bruxelles-Capitale (238\% of the average) and Luxembourg ( $234 \%$ of the average). The poorest regions of the Union are located in Poland with $33 \%$ of the average. 37 regions exceeded $125 \%$ 
of the EU-25 average. This included seven regions in Germany, six each in Italy and the United Kingdom, five in the Netherlands, three in Austria, two each in Belgium and Finland, and one region each in the Czech Republic, Spain, France, Ireland, Sweden and Luxembourg. Sixty regions of the European Union had a GDP of below $75 \%$ of the EU-25 average. This included sixteen in Poland, seven in the Czech Republic, six in Hungary, five each in Greece and Italy, four each in German, France and Portugal, three in Slovakia, and two in Spain, Estonia, Latvia, Lithuania and Malta. The six lowest regions in the ranking were all in Poland. The lowest ranked region amongst the old Member States was Norte in Portugal with 57\%. Because of the huge gap between member states, it looks that, the Structual Funds will continue to be one of the most important policy tool and expenditure item for the European Union in the future. 


\section{References:}

Bailey, D. \& De Propris, L., (2004). A Bridge Too Phare? EU PreAccession Aid and Capacity-Building in the Candidate Countries, Journal of Common Market Studies, Volume 42, No: 1, 77-98.

Boldrin, M. \& Canova, F., (2001). Inequality and Convergence: Reconsidering European Regional Policies, Economic Policy, 16 (32), 205-253.

Brunazzo, M. \& Piattoni, S. (2004). Negotiating the Regulation of the Structural Funds: Italian Actors in EU Regional Policy-Making, Modern Italy, November 2004, 9 (2), 150-172.

Cappelen, A., Casetellacci, F., Fagerberg, J. \& Verspagen, B. (2003). The Impact of EU Regional Support on Growth and Convergence In the European Union, Journal of Common Market Studies, Vol.41, No:4, 621-644.

De Rynck, S. \& McAleavey, P. (2001). The Cohesion Deficit in Structural Fund Policy, Journal of European Public Policy, 8:4 August, 541-557.

Ederveen, S. \& Gorter, J. (2002). Does European Cohesion Policy Reduce Regional Disparities?, CPB Discussion Paper, No: 15.

European Commission (2006). The Growth and Jobs Strategy arid the Reform of European Cohesion Policy: Forth Progress Report on Cohesion, COM (2006), Brussels.

European Commission (2003). Structural Policies and European Territories: Competitiveness, Sustainable Development and Cohesion in Europe From Lisbon to Gothenburg, Office for Official Publications of the European Communities, Luxembourg.

European Commission (2003). Annual Report of the Cohesion Fund, Commission of the European Communities, Brussels.

European Commission (2006). Press Releases, Memo/06/410, Brussels, 8 November 2006.

European Commission (2004). Working for the Regions, Office for Official Publications of the Euorpean Communities, Luxembourg.

Fenge, R. \& Wrede, M. (2004), EU Regional Policy: Vertical Fiscal Externalities and Matching Grants, CESifo Working Paper, No: 1146, München. 
Florio, M. (2006). Cost-Benefit Analysis and the European Union Cohesion Fund: On the Social Cost of Capital and Labour, Regional Studies, 40 (2), 211-224.

Heijman, W. (2001). European Structural Policy: Bend or Break, European Journal of Law and Economics, March 2001, 11 (2), 165-175.

Inforegio (2005). New Initiatives of Regional Policy, December 2005, No: 141.

Inforegio (2006). New Instrument for Pre-Acression Assistance, Octobo: 2006, No: 150.

Inforegio (2006). Regions and Cities for Growth and Jobs: An Overview of Regulations 2007-2013 on Cohesion and Regional Policy, Factsheet, 2006.

Jaspers: A new Technical AssistanceParnership. Retrieved: 01.10.2007 from http://ec.europa.eu/regional_policy/funds/2007/jj//jaspers_en.html.

Jeremie: Improved Access to Finance for Micro Business and SMEs in the Regions of the EU. Retrived: 01.10.2007 from http://ec.europa.eu/regional_policy/funds/2007/jjj/jeremie_en.html.

Jessica: Sustainable Development for Uraban Areas. Retrived: 01.10.2007 from http://ec.europa.eu/regional_policy/funds/2007/jjj/jessica_en.html,

Kuitunen, S. (2002). What is the Role of the EU Structural Funds in Promoting RTDI? Review of Some Empirical Findings, Research Evulation, Volume: 11, No: 1, 49-58.

Rodfiguez-Pose, A. \& Fratesi, U. (2004). Between Development and Social Policies: The Impact of European Structural Funds in Objective 1 Regions, Regional Studies, Vol. 38.1, February, 97-113.

Sutcliffe, J. B. (2000). The 1999 Reform of the Strucutural Fund Regulations: Multi-level governance or Renationalization?, Journal of European Public Policy, 7(2), 290-309. 